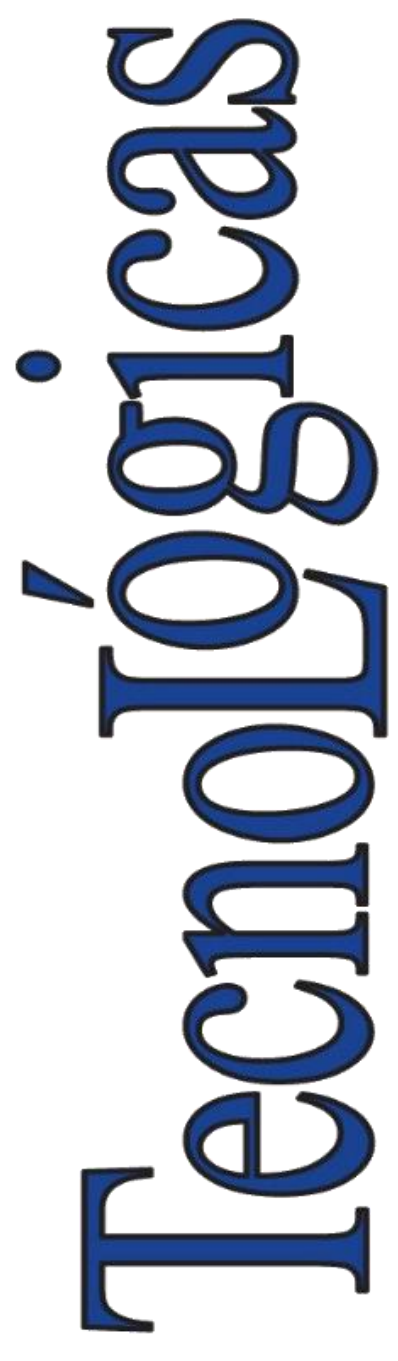

ISSN-p: 0123-7799 ISSN-e: $2256-5337$

Vol. 24, nro. 52, e2111, 2021

Recibido: 02 agosto 2021 Aceptado: 10 noviembre 2021 Disponible: 16 diciembre 2021

CInstituto Tecnológico Metropolitano Este trabajo está licenciado bajo una Licencia Internacional Creative Commons Atribución (CC BY-NC-SA)

\section{Dissolved Air Flotation: A Review from the Perspective of System Parameters and Uses in Wastewater Treatment}

\author{
Flotación por aire disuelto: una revisión desde la \\ perspectiva de los parámetros del sistema y usos en el \\ tratamiento de aguas residuales
}

(D) Jeimmy Adriana Muñoz-Alegría ${ }^{1}$;

(iD) Elena Muñoz-España2;

iD Juan Fernando Flórez-Marulanda ${ }^{3}$

1 Universidad del Cauca, Popayán-Colombia, jeimymunoz@unicauca.edu.co

2 Universidad del Cauca, Popayán-Colombia, elenam@unicauca.edu.co

${ }^{3}$ Universidad del Cauca, Popayán-Colombia, jflorez@unicauca.edu.co

How to cite / Cómo citar

J. A. Muñoz-Alegría; E. Muñoz-España; J. F. Flórez-Marulanda, "Dissolved Air Flotation: A Review from the Perspective of System Parameters and Uses in Wastewater Treatment", TecnoLógicas, vol. 24, nro. 52, e2111, 2021. https://doi.org/10.22430/22565337.2111 


\section{Abstract}

The current issues of climate change and high freshwater demand worldwide have promoted the implementation of wastewater reclamation technologies. This study aims to review the efficiency of the dissolved air flotation (DAF) technique in a wide variety of applications in the agricultural, industrial, domestic, and municipal sectors, which have high freshwater consumption worldwide. We made a systematic review of the DAF technique in wastewater treatment in 2015-2021. We reviewed six indexed databases and governmental statistical reports; we used the keywords: dissolved air flotation, microbubbles, wastewater treatment, and the main operating and design parameters involved in the effectiveness of the flotation process. Additionally, we conducted a review of the most common synthetic coagulant studies used with DAF, as well as natural coagulants that promise to mitigate current climate change. Finally, we discussed advantages, disadvantages, and potential future studies. DAF to have considerable potential for wastewater treatment, as well as for waste utilization. The generation of large quantities of DAF sludge is a breakthrough for clean energy production, as it allows the use of this waste for biogas production.

\section{Keywords}

Dissolved air flotation, Microbubbles, Wastewater treatment, Design and operating parameters, coagulation-flocculation.

\section{Resumen}

La actual problemática de cambio climático y alta demanda de agua dulce a nivel mundial ha promovido la implementación de tecnologías para la regeneración de las aguas residuales. El objetivo de este estudio es revisar la eficiencia del sistema de flotación por aire disuelto (DAF) en una amplia variedad de aplicaciones en los sectores agrícola, industrial, doméstico y municipal, los cuales presentan un elevado consumo de agua dulce en el mundo. Por tal motivo se realizó una revisión sistemática de la técnica de DAF utilizada para el tratamiento de aguas residuales en el periodo 2015-2021. Se revisaron seis bases de datos indexadas y reportes estadísticos gubernamentales, las palabras claves fueron flotación por aire disuelto, microburbujas, tratamiento de aguas residuales y los principales parámetros de operación y diseño que intervienen en la eficacia del proceso de flotación, junto con un análisis de los estudios de coagulantes sintéticos más comunes utilizados con DAF, así como de los coagulantes naturales que prometen mitigar el cambio climático actual. Por último, se discuten las ventajas, los inconvenientes y los posibles estudios futuros. Se observó que DAF tiene un potencial considerable para el tratamiento de aguas residuales, así como para la utilización de residuos. La generación de grandes cantidades de lodos de DAF es una brecha para la producción de energía limpia, pues permite utilizar estos residuos para la producción de biogás.

\section{Palabras clave}

Flotación por aire disuelto, microburbujas, tratamiento de aguas residuales, parámetros de diseño y operación, coagulación-floculación. 


\section{INTRODUCTION}

The effects of climate change and the growing demand for water worldwide have generated an alarming water deficit. The global population is expected to reach nearly 8.6 billion by 2030, and water demand is expected to grow annually by $1 \%$, resulting in a cumulative increase of $20 \%$ to $30 \%$ by 2050 [1]. Social development activities demand considerable amounts of freshwater, with the agricultural sector accounting for an estimated $70 \%$ of the total water consumption, the industry for $19 \%$, and the remaining $11 \%$ used for domestic and municipal needs [2]-[4].

Numerous water recovery methods have been developed. They include chemical, biological, and physical techniques such as gravity separation, membrane filtration, flotation, and electrocoagulation [5]-[8]. In recent years, microbubble (MB) and nanobubble (NB) technologies have been integrated into water clarification processes [9]-[12], particularly in methods such as flotation, disinfection, and advanced oxidation [13]. The physicochemical properties and free radicals cause the bubbles [14], [15] to remove fine particles easily [10], [16], [17].

This has been proven in wastewater treatment [18]; in the removal of oil, grease and Total Petroleum Hydrocarbon (TPH) in the petroleum industry [12], [15], [19]; and in the removal of Fats, Oil and Grease (FOG) from domestic wastewater [20]-[22]. MBs effectively degrade antiviral, antibacterial, anticancer, psychotropic, antihypertensive, analgesic, and antipyretic pharmaceuticals mixed in water by increasing the removal rates, thus reducing the discharge of these products into river environments [23] and improving, for example, the quality of rivers and groundwater contaminated with organic substances [24].

Dissolved Air Flotation (DAF) is a reliable method for wastewater treatment [22], [25][27]. It has already been applied to the treatment of fluids with different characteristics, from drinking water and wastewater to industrial water [28]. The efficiency of DAF has encouraged the integration of hybrid technologies with positive results in pollutant removal, meeting environmental discharge standards of turbidity, color, Total Suspended Solids (TSS), Chemical Oxygen Demand (COD), and Biochemical Oxygen Demand (BOD). It has also been used for oil, grease, and fine particulate removal [29]-[31]. DAF applications in wastewater treatment have enabled its technological advancement in recent years [32],[33].

DAF is effective in removing low-density components present in elements and chemical compounds, plant compounds, microorganisms, and parasites. In eutrophic waters, DAF has maintained stable removal efficiencies in the removal of turbidity, total phosphorus, chlorophyll, and COD of $80 \%, 72 \%, 71 \%$, and $61 \%$, respectively. In addition, dissolved oxygen in polluted urban rivers could be raised from 0.2 to $2 \mathrm{mg} / \mathrm{L}$ to 3 to $3.5 \mathrm{mg} / \mathrm{L}$ due to air dissolved in water, mitigating the negative impact on the environment [34]. Another study showed an efficiency between $11.1 \%$ and $77.7 \%$ in COD removal by DAF and aluminumbased coagulants from wastewater generated by a cosmetics factory. However, wastewater from the production of UV filter creams was resistant to DAF treatment regardless of the coagulant [35].

The efficiency of DAF in the removal of antibiotics has been evaluated in wastewater from the pharmaceutical sector, showing COD and penicillin G potassium removal percentages of $70.41 \%$ and $67.45 \%$, respectively, under optimal conditions in the operation of the system [36]. In Colombia, an important study by ECOPETROL S.A. led to the design of a new flotation system for water treatment in the oil industry. A $75 \%$ separation efficiency was obtained in production waters using DAF compared to Induced Air Flotation (IAF) [37], [38]. 
Hybrid treatment methods combined with biological and physicochemical treatment processes have been adopted with high efficiency in wastewater treatment plants (WWTPs) [31]. They generally comprise fast precipitation, hydro cyclones, and DAF as a final complementary stage. Due to the physicochemical properties of MBs, the DAF technique can advantageously remove microparticles and non-settled material from WWTPs with low operating costs and short hydraulic retention times [39].

DAF is an excellent complementary stage. A study tested the efficiency of DAF in conjunction with a pilot-scale high-speed activated sludge system of the municipal water treatment plant in Aartselaar (Belgium). Sand was first removed by sedimentation, and then large particles (size $1 \mathrm{~mm}$ ) were removed by a drum filter. Finally, the liquid was transferred to the DAF unit, where special conditions were used to further clean the water. The results showed a removal of $78 \%$ of TSS and $68 \%$ of COD [30].

Another study recently evaluated the ability of DAF as a possible new mechanism to diagnose intestinal parasites in feces. The results showed parasite recovery efficiencies of $73.27 \%$, $58.12 \%, 37.85 \%$, and $91.89 \%$ for Ascaris lumbricoides, Hymenolepis diminuta, Giardia duodenalis, and Strongyloides stercoralis, respectively. This reveals a promising line of research for DAF, as intestinal parasitosis is a severe public health problem globally [40].

In general, the DAF technology is efficient in water treatment; it also has favorable operating costs and can be very attractive if it integrates renewable energies in all its processes. Studying the trends of DAF allows us to foresee its efficiency in future studies because some environments present more complex compositions than others.

Therefore, reviewing different DAF applications enables us to indirectly identify the strengths and limitations of these systems to optimize the technique.

This paper reviews the literature published between 2015 and 2021 about the applications of DAF in the agricultural, industrial, and domestic and municipal sectors. It examines the functionality of DAF systems (including coagulation-flocculation) and their applications in wastewater treatment. It also identifies the main design and operating parameters that determine the efficiency of the cleaning process in conventional DAF. Finally, the advantages and disadvantages of the technology, its advances, and areas of possible future work are highlighted.

\section{METHODS}

This literature review adopted the systematic search method [41], [42], which is composed of three stages: application of search strings, exclusion criteria, and information analysis (see Figure 1). We carried out an exhaustive search in six databases (ScienceDirect, Scopus, Springer, Web of Science, IWA Publishing, and SciELO) and government statistical reports from the United Nations' websites. We formulated search strings to find wastewater treatments using DAF and MB technology. The main keywords used for this purpose were dissolved air flotation, microbubbles, wastewater treatment, and operation and design parameters. We applied two exclusion criteria to select the most relevant information: (a) research and review articles published before 2015 and (b) documents such as conference material, books, or research thesis. Finally, relevant data extraction and analysis resulted in a list of 106 papers about DAF in different applications.

However, this literature review also includes eight papers published before 2015 and two website references that corroborate the vast experience of the DAF technique since its beginnings. 


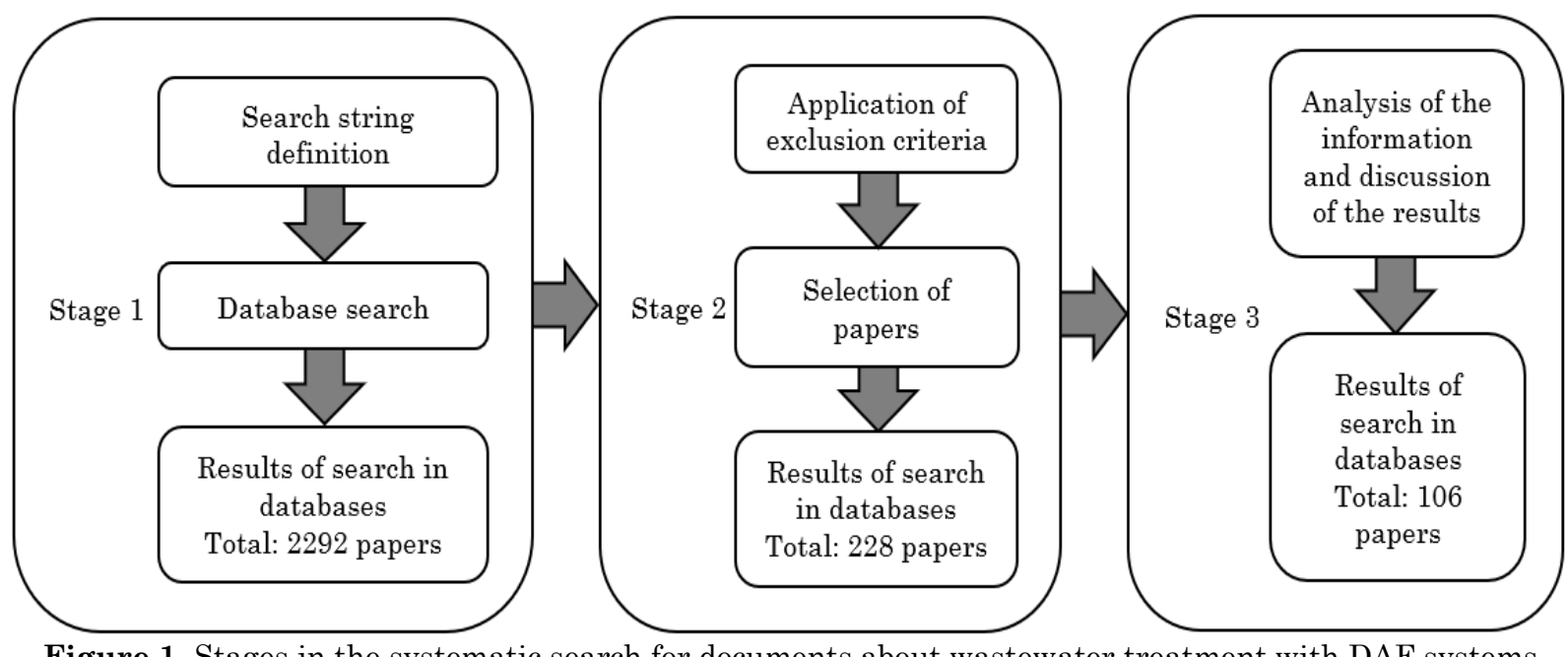

Figure 1. Stages in the systematic search for documents about wastewater treatment with DAF systems Source: Created by the authors.

\section{RESULTS}

\subsection{Dissolved Air Flotation}

In the 1970s, the DAF method was already being used in drinking and wastewater treatment in Finland, Sweden, and South Africa [43]. Currently, DAF has a superior performance in water recovery in the industrial, agricultural, and domestic-municipal sectors.

DAF separates fine particles from the flow by means of MBs. Conventional DAF involves four processes: MB generation, chemical pretreatment of the wastewater, flotation, and sludge removal. Structurally, the technique consists of a flotation tank divided into two zones (contact and separation) by a baffle. The contact zone guarantees the collision and adhesion of the particles to the MBs, which are then conveyed to the separation zone. This MB-particle agglomeration rises to the surface by the force of buoyancy, forming sludge or a foam layer.

In many cases, depending on the wastewater to be treated, a coagulation-flocculation process is used before the flotation tank to ensure better adhesion of the microparticles to the bubbles [44]-[46]. Finally, the sludge removal stage is generally composed of a skimmer system that extracts the waste for further treatment [47] (see Figure 2).

Microbubbles are generated by the precipitation caused by the sudden depressurization at high pressures (usually $300-700 \mathrm{kPa}$ ) of a mixture of water and air in a saturator (a tank or Venturi tube). The generated bubbles are driven to the contact zone [48]. In general, the total amount of air transported to the contact zone depends on the saturator pressure and the recycle flow $(\mathrm{Qr})$ [43].

The optimal size of the MBs in DAF is usually between $20 \mu \mathrm{m}$ and $100 \mu \mathrm{m}$ [49]. The smaller the bubbles, the greater their chance of collision with suspended particles [26], [50].

Computer vision and machine learning algorithms [51], [52] are highly useful for estimating characteristic bubble parameters, such as shape [53], size [54], [55], and rise velocity [56]. They can also be used to monitor the flotation process closely [16] (see Figure 3). 


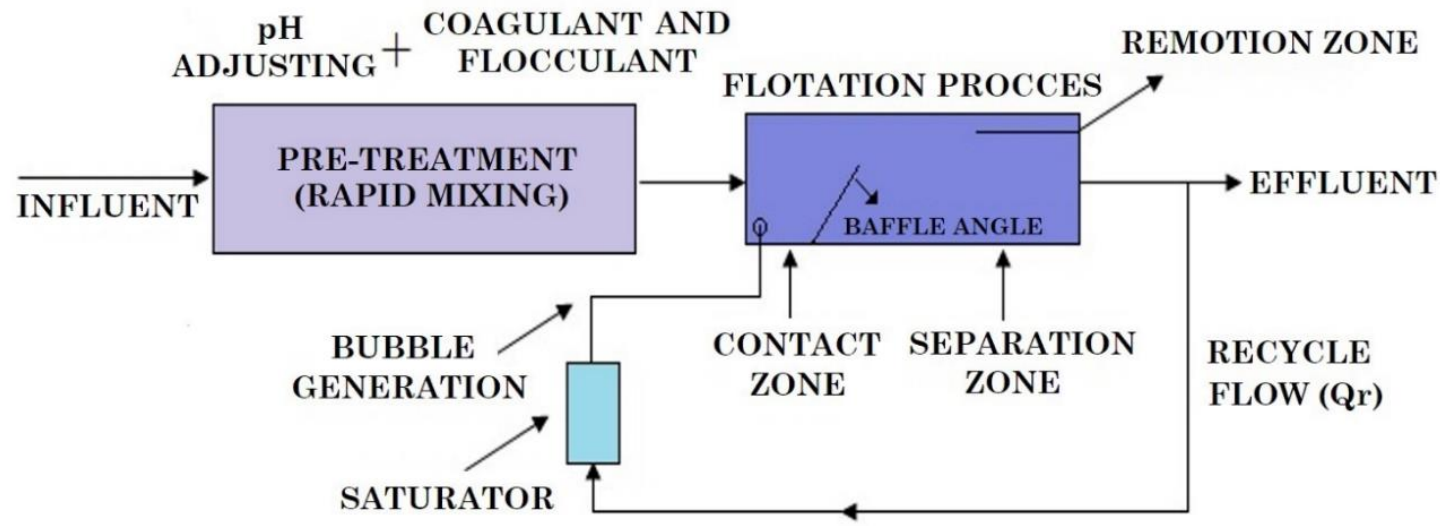

Figure 2. Process diagram of conventional DAF. Source: Created by the authors.
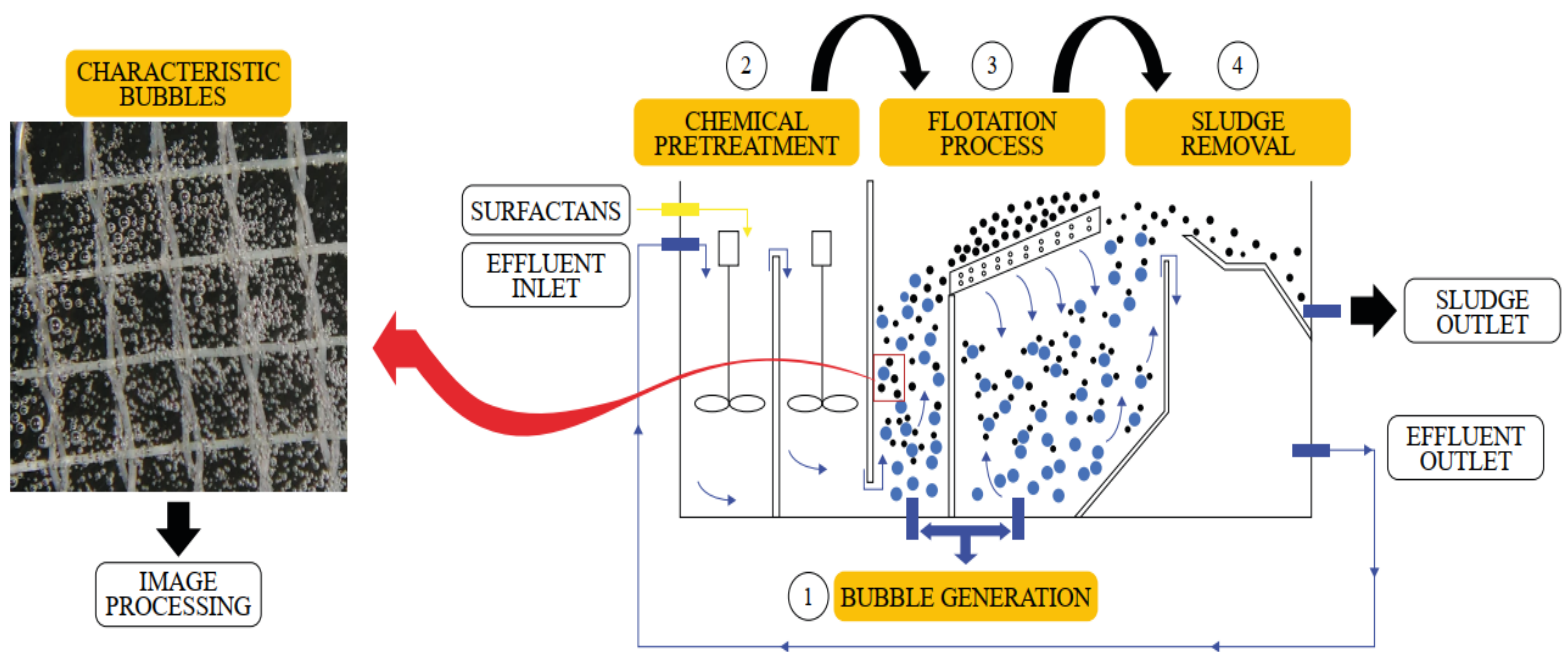

Figure 3. Main steps in conventional DAF. Source: Created by the authors.

\subsection{Applications of DAF in water treatment}

This subsection describes DAF applications classified by sector: agricultural, industrial, and domestic and municipal.

\subsubsection{Agricultural sector}

Multiple publications have studied the efficiency of DAF in the treatment of wastewater from the dairy, slaughterhouse, and poultry industries. Dairy wastewater is characterized by high FOG, COD, and BOD contents, as well as the formation of sludge with strong butyric acid odor attributed to the decomposition of casein [57]. The release of dairy effluents without prior treatment into bodies of water can have a negative impact on ecosystems due to high TSS and turbidity levels [57], [58]. Table 1 details these studies along with the main removal parameters they reported. 
Table 1. Application of DAF in agricultural wastewater. Source: Created by the authors.

\begin{tabular}{|c|c|c|c|c|c|c|c|c|}
\hline \multirow[b]{2}{*}{ No. } & \multirow[b]{2}{*}{ Wastewater type } & \multicolumn{6}{|c|}{ Principal physicochemical parameters Removal efficiency (\%) } & \multirow[b]{2}{*}{ Ref. } \\
\hline & & $\begin{array}{l}\text { Oil and } \\
\text { grease }\end{array}$ & TSS & COD & BOD & Color & Turbidity & \\
\hline 1 & Dairy & - & - & 87.5 & - & 83.1 & 97.8 & {$[57]$} \\
\hline 2 & Dairy & - & 62.5 & 87.8 & 91.4 & - & - & [59] \\
\hline 3 & Slaughterhouses & - & - & 90.0 & 90.0 & - & - & {$[5]$} \\
\hline 4 & Poultry & - & - & 97.9 & 98.6 & - & - & {$[60]$} \\
\hline 5 & Poultry & $91.1 \pm 5.2$ & - & $97.9 \pm 1.0$ & $98.6 \pm 1.0$ & - & - & [61] \\
\hline 6 & $\begin{array}{l}\text { Harvesting of } \\
\text { Chlorella sorokiniana }\end{array}$ & - & $88.6-92.5$ & - & - & $91.7-92.3$ & $93.7-96.2$ & [58] \\
\hline 7 & Dairy & 66.1 & 95.0 & 54.2 & 76.2 & 83.2 & 88 & {$[62]$} \\
\hline 8 & Dairy & - & - & $48.3-50.3$ & - & - & $91.1-91.5$ & [63] \\
\hline
\end{tabular}

Wastewater from the slaughterhouse industry is characterized by high levels of Organic Matter (OM), nutrients, pathogens, detergents, FOG, and sometimes antibiotics and heavy metals [5], [60]. DAF has also been highlighted as one of the most promising advanced technologies for wastewater treatment in the poultry sector [61]. In this industry, effluents are characterized by high levels of proteins, fats, organic and inorganic phosphates, and carbohydrates [60].

\subsubsection{Industrial sector}

DAF has been applied in wastewater treatment in the paper manufacturing [64], mining [45], and metalworking [29], [65] industries. Likewise, it has also been used in desalination [66], oil recovery, and oil and grease removal [67]-[69]. Representative removal parameters for various industrial effluents are provided in Table 2.

Table 2. DAF application in industrial wastewater. Source: Created by the authors.

\begin{tabular}{|c|c|c|c|c|c|c|c|c|}
\hline \multirow[b]{2}{*}{ No. } & \multirow[b]{2}{*}{ Wastewater type } & \multicolumn{6}{|c|}{ Physicochemical parameters Removal efficiency (\%) } & \multirow[b]{2}{*}{ Ref. } \\
\hline & & $\begin{array}{l}\text { Oil and } \\
\text { grease }\end{array}$ & TSS & COD & BOD & Color & $\mathrm{TPH}$ & \\
\hline 1 & Biodiesel & $98.0-99.6$ & $98.0-100.0$ & $80.0-90.0$ & $80-90$ & No color & - & {$[70]$} \\
\hline 2 & Metalworking fluids & - & - & 99.8 & - & - & 98.9 & [29] \\
\hline 3 & Emulsified oil & $>90.0$ & - & - & - & - & - & [12], [69] \\
\hline 4 & $\begin{array}{l}\text { Wastewater from the } \\
\text { petrochemical and food } \\
\text { processing industries }\end{array}$ & 99.7 & - & 95.0 & - & - & $>90.0$ & {$[71]$} \\
\hline 5 & Wastepaper industry & - & 98.1 & $\begin{array}{c}39.0 \pm \\
10.0\end{array}$ & - & $33 \pm 20$ & - & {$[44]$} \\
\hline 6 & $\begin{array}{l}\text { Metalworking } \\
\text { wastewater }\end{array}$ & 99.7 & - & 98.5 & 61 & - & 70.0 & [65] \\
\hline 7 & Water emulsions & - & - & 100.0 & - & - & - & [68] \\
\hline 8 & Oilfield wastewater & 96.6 & 88.8 & 95.7 & - & - & - & [19] \\
\hline
\end{tabular}

In some cases, DAF as primary treatment is insufficient to meet the removal parameters established by environmental regulations; therefore, it is necessary to incorporate other methods, which typically include biological treatments [19]. 
Other important removal parameters for industrial wastewater include heavy metals, radioactive waste, and $\mathrm{OM}$. The removal of heavy metals and other chemical compounds in wastewater is a problem encountered in the metallurgical [29] and mining industries [72].

DAF has shown effective removal results for such elements and other chemical components (see Table 3).

Table 3. Application of DAF in the removal of metals and chemical compounds. Source: Created by the authors.

\begin{tabular}{cccc}
\hline No. & Element & Removal efficiency (\%) & Reference \\
\hline 1 & Sulfate ions & 82.0 & {$[73]$} \\
2 & Fe $(\mathrm{OH})_{3}$ & 99.0 & {$[9]$} \\
3 & Amina & 80.0 & {$[18]$} \\
4 & Lead and zinc sulfide & $89.0-96.0$ & {$[45]$} \\
5 & (particles $<44 \mu \mathrm{m})$ & 95.0 & {$[45]$} \\
6 & Fe ions & $29.0,27.0,31.0$, and 29.0 & {$[25]$} \\
7 & $\mathrm{Cd}, \mathrm{Ni}, \mathrm{Mn}$, and $\mathrm{Pb}$ & 97.6 & {$[74]$} \\
8 & Sodium oleate $(\mathrm{NaOL})$ & $>95.0$ & {$[71]$} \\
9 & $\mathrm{Cu}, \mathrm{Cd}$, and $\mathrm{Zn}$ & $>90.0$ & {$[75]$} \\
10 & Acrylonitrile-butadiene-styrene & $95.0-100.0$ & {$[76]$} \\
\hline
\end{tabular}

In some cases, ultrafine metallic particles are difficult to remove in the cleaning process, making it necessary to use flocculants and/or coagulants that facilitate the adhesion of the particles to the bubbles [65]. In one study [25], different polymers (polyvinyl alcohol, polyethylene glycol, and chitosan) were investigated as collectors to remove heavy metals (zinc chloride, lead nitrate, manganese chloride, nickel chloride, and cadmium chloride) from wastewater using DAF. The results showed better removal efficiency for chitosan than the other candidates.

The nuclear industry generates gaseous, liquid, and solid radioactive wastes that require specialized treatment due to their high degree of toxicity and contamination [77], [78]. In one study [46], the treatment of radioactive liquid waste using a mobile DAF system was examined. The results showed high removal levels of $95 \%$ for concentrations of oil waste, $\mathrm{SO}_{4}^{-2}, \mathrm{NO}^{3-}, \mathrm{PO}_{3}{ }^{3-}, \mathrm{Ni}$, and $\mathrm{Cr}$, as well as removal levels of approximately $94 \%$ for total Co, and $75 \%$ for ${ }^{60} \mathrm{Co}$.

Finally, another important removal parameter is OM [79]. It has been shown that DAF can remove more than $98 \%$ of the OM [29] present in fresh and saline wastewater [80] and in desalination pretreatment systems [66] under specific coagulation conditions. DAF has been reported to remove $38-84 \%$ of the biopolymers and $20-61 \%$ of the humic substances, two main organic fractions.

\subsubsection{Domestic and municipal sector}

DAF has been used in the treatment of a variety of wastewater types generated by the domestic and municipal sector (see Table 4), showing efficient results in combination with other methods [22], [30], [31], [81]. The primary contaminants in these wastewaters are OM, nitrogen, organic carbon, phosphorus, and FOG [21], [39], in addition to microorganisms [82] and biodegradable particles [83]. 
Table 4. Application of DAF in different types of wastewaters from the domestic and municipal sector Source: Created by the authors.

\begin{tabular}{|c|c|c|c|}
\hline No. & Wastewater type & Removal efficiency (\%) & Reference \\
\hline 1 & Phosphorus and organic matter removal & 82 (Total phosphorus & {$[39]$} \\
\hline 2 & Pharmaceutical products removal & 71 (Diclofenac) & {$[31]$} \\
\hline 3 & Organic compounds (domestic wastewater) & 78 (TSS) & {$[30]$} \\
\hline 4 & Residential/municipal wastewater & - & {$[22],[58][81],[83],[84]$} \\
\hline 5 & Restaurants & 92.4 (Oil) & {$[85]$} \\
\hline 6 & Giardia and Cryptosporidium protozoa & $\begin{array}{l}\text { 95.38-99.81 (Total } \\
\text { Coliforms, TC, and E. coli) }\end{array}$ & {$[82],[86]$} \\
\hline
\end{tabular}

In general, physicochemical removal parameters such as OM, nitrogen, organic carbon, phosphorus, and FOG (which are derived from the use of cleaning or pharmaceutical products and other domestic activities) are treated with bacterial cultures in activated sludge systems [21], [87]. However, in [30], the efficiency of high-rate activated sludge systems combined with DAF was examined to determine if they improved solid-liquid separation. In this respect, a removal of $78 \%$ of TSS and $68 \%$ of COD was obtained under specific coagulation conditions.

Municipal and domestic wastewater also contains microorganisms that can be highly infectious. The effect of DAF in the presence of coagulants to remove Giardia and Cryptosporidium has been studied in [82] and [86]. It was shown that DAF is a potential treatment to remove Giardia cysts from effluents, providing low protozoa concentration and turbidity. A combined coagulation-DAF process has been employed [84] to reduce Antibiotic Resistance Genes (ARG) in the influent of a wastewater treatment plant using three types of coagulants ( $\mathrm{PACl}, \mathrm{FeCl}_{3}$, and $\left.\mathrm{Al}_{2}\left(\mathrm{SO}_{4}\right)_{3}\right)$. The results showed that this combined process is a more efficient means to remove TSS and COD, as well as ARG.

DAF's recovery of biodegradable particles has been studied by evaluating its TSS removal efficiency in screened municipal wastewater effluents [83]. The results showed TSS removal without chemicals at a low surface loading rate $(<15 \mathrm{~m} / \mathrm{h})$ and a high recycling ratio of $94 \pm 1 \%$.

As for potable water, there are no recent studies that encourage the use of DAF. However, the literature reports the application of DAF as a clarifier for drinking water in the 1960s [43]. Crossley and Valade conducted a review of DAF technology since then, particularly regarding potable water production [88]. More recently, other authors [28] have studied the optimization of a treatment plant design using DAF technology in Kluizen, Belgium.

\subsubsection{Operating and design parameters of DAF}

Identifying the parameters of DAF systems requires an understanding of the stages of the cleaning process. In the case of conventional DAF systems, there are three important processes: chemical pretreatment (coagulation-flocculation), MB generation, and flotation.

They present a wide variety of operating and design parameters. This paper proposes a selection of main DAF parameters to highlight their relevance in the assessment of wastewater treatment efficiency.

The working principle of DAF systems is the flotation process, which, in essence, uses air MBs to capture microparticles and then separates the emulsions produced based on their physicochemical properties [33]. It has been shown that a reduction in bubble size increases the contact angle and bond strength between particles; this, in turn, increases opportunities 
for floc formation [54], [55], [89]. The optimal bubble size is usually between $20 \mu \mathrm{m}$ and $100 \mu \mathrm{m}$ [49] (see Table 5).

Indeed, the study of $\mathrm{MB}$ characteristics in the flotation process helps to ensure MB stability and removal efficiency [53], [90], [91]. The larger the diameter of the bubble, the higher its rising velocity and thus the shorter its lifetime [92]-[94]. For this reason, physical factors (i.e., pressure, dissolved air flow, and temperature) are important in the generation of MBs. The flotation process involves different parameters that depend on optimal MB generation, the contact between bubbles, and the characteristics of the wastewater [48], [95].

DAF parameters are directly related to the setup of DAF processes and, therefore, vary when coagulation or flocculation is used [58], [96]. According to the literature, a number of parameters can affect optimal generation of $\mathrm{MBs}$ in terms of number, diameter, and rising velocity, as well as the efficiency of waste removal [93], [97], [98]. For example, they include air pressure, water inlet flow rate, and injected air flow [50], [99] (dissolved oxygen, DO, generally 0.5-5.5 mg/l), which determine optimal MB generation [22], as well as the recycle flow rate or Recirculation Rate (\% R, $10 \%$ being typical in DAF) [54], [100], [101]. Table 5 details the operating parameters most commonly reported in the studies cited above.

Table 5. Main operating parameters of a conventional DAF system. Source: Created by the authors.

\begin{tabular}{|c|c|c|c|c|c|}
\hline No. & Reference & $\begin{array}{l}\text { Diameter } \\
\mathrm{MB}(\mu \mathrm{m})\end{array}$ & $\begin{array}{l}\text { Air pressure } \\
(p s i)\end{array}$ & $\% \mathrm{R}$ & Removal efficiency (\%) \\
\hline 1 & $\begin{array}{c}{[102]} \\
\text { Analytical and } \\
\text { CFD models }\end{array}$ & $40-50$ & $65.27-87.02$ & $5-20$ & - \\
\hline 2 & {$[80]$} & - & 72.52 & 20 & $\begin{array}{l}100 \text { (algal cells), } 99.99 \text { (Adenosine Tri- } \\
\text { Phosphate (ATP)) }\end{array}$ \\
\hline 3 & [68] & - & 72.52 & - & $70(\mathrm{DQO})$ \\
\hline 4 & {$[58]$} & 40 & 72.52 & 20 & 98 (Chlorella sorokiniana) \\
\hline 5 & {$[45]$} & - & 87.02 & $20-25$ & 89-96 (Particles < $44 \mu \mathrm{m})$ \\
\hline 6 & [103] & $40-80$ & Patm & - & 52 (Particle removal) \\
\hline 7 & $\begin{array}{c}{[67]} \\
\text { Analytical and } \\
\text { CFD models }\end{array}$ & 45 & $14.50-58.02$ & $20-29$ & 76.6 (Oil droplets) \\
\hline 8 & [63] & - & 116.03 & 20 & 91.5 (Turbidity in dairy wastewater) \\
\hline 9 & {$[62]$} & - & 145.04 & 20 & > 90 (Turbidity in dairy wastewater) \\
\hline 10 & {$[57]$} & - & $58.02-145.04$ & $20-100$ & 97.8 (Turbidity in dairy wastewater) \\
\hline 11 & {$[46]$} & $40-60$ & 89.92 & 40 & $\begin{array}{l}99(\mathrm{Ni}, \mathrm{Cu}, \mathrm{Cr}, \mathrm{Pb} \text { liquid radioactive } \\
\text { waste) }\end{array}$ \\
\hline
\end{tabular}

*\% R: Recirculation rate

On the other hand, coagulation and flocculation are chemical pretreatment processes that affect the performance of DAF since they alter the properties of the wastewater to be treated.

The coagulation process consists of the electrical destabilization of the particles, and flocculation is the process in which the particles collide with each other to form larger clots, which facilitates the removal of turbidity, color, and pathogenic microorganisms, among other things [104]. Therefore, flocculants, coagulants, surfactants, and other chemical compounds are necessary to obtain an efficient treatment in the complex wastewater treatment plants used in the industrial, domestic, and municipal sectors [80].

Typically, in DAF systems, two units are integrated for coagulation-flocculation as a pretreatment of the wastewater before the flotation process is applied [64], [88]. During 
flotation, these pretreatments alter the $\mathrm{pH}$ and Zeta potential in particular, which can affect particle-MB interaction and floc formation [16], [74], [105]. For this reason, it is essential to know the type of coagulant, flocculant, optimal dosage, $\mathrm{pH}$, mixing time, velocity, and reaction time (see Table 6 ).

Table 6. DAF parameters with coagulation or flocculation. Source: Created by the authors.

\begin{tabular}{|c|c|c|c|c|c|c|c|c|}
\hline No. & Coagulant & Flocculant & $\mathrm{pH}$ & $\begin{array}{c}\text { Mixing } \\
\text { velocity } \\
{[\mathrm{rpm}]} \\
\end{array}$ & $\begin{array}{l}\text { Mixing } \\
\text { time } \\
\text { [min] }\end{array}$ & $\begin{array}{l}\text { Floc. } \\
\text { time } \\
{[\mathrm{min}]}\end{array}$ & $\begin{array}{l}\text { Removal } \\
\text { efficiency } \\
(\%)\end{array}$ & Ref. \\
\hline 1 & $\begin{array}{l}\text { Ferrous sulfate } \\
\left(\mathrm{FeSO}_{4}\right)\end{array}$ & $\begin{array}{l}\text { Cationic } \\
\text { polymer } \\
\text { TanFloc }\end{array}$ & 4.0 & 120 & 5 & - & 97.8 (Turbidity) & [57] \\
\hline 2 & $\begin{array}{l}\text { Chitosan/ } \\
\text { polyaluminum } \\
\text { ferric chloride } \\
\text { (PAFC) }\end{array}$ & - & 6.0 & $50-200$ & $5-15$ & - & $\begin{array}{l}64.3 \text { (Organic } \\
\text { pollutants) }\end{array}$ & [27] \\
\hline 3 & $\begin{array}{l}\text { Aluminum } \\
\text { sulphate, ferric } \\
\text { chloride, Tanfloc } \\
\text { SG and Zetag } 8185\end{array}$ & - & 7.0 & - & - & $15-30$ & $\begin{array}{l}\text { 89.4-90.9 (Total } \\
\text { phosphorus) } \\
90.2-92.6 \text { (Total } \\
\text { Kjeldahl nitrogen, } \\
\text { TKN) }\end{array}$ & [58] \\
\hline 4 & $\begin{array}{l}\text { Combined } \\
\text { polyacrylamide } \\
\text { (PAM) }\end{array}$ & Tanfloc & 7.6 & 120 & 5 & 5 & >90 (Turbidity) & {$[62]$} \\
\hline 5 & $\begin{array}{l}\text { Liquid ferrate/ } \\
\text { Ferric chloride }\end{array}$ & - & $\begin{array}{c}(8.0 \pm 0.20 \\
\quad)\end{array}$ & 100 & 2 & 20 & $\begin{array}{l}92 \text { (Organic } \\
\text { matter) }\end{array}$ & [80] \\
\hline 6 & $\begin{array}{l}\text { Ripe Okra } \\
\text { (Abelmoschus } \\
\text { esculentus) / } \\
\text { passion fruit } \\
\text { (Passiflora edulis) }\end{array}$ & - & $9 / 5$ & 200 & 1 & 15 & 91.1 (Turbidity) & [63] \\
\hline 7 & $\begin{array}{l}\text { Ferric chloride } \\
\left(\mathrm{FeCl}_{3}\right)\end{array}$ & $\mathrm{PACl}$ & $2.5-3.0$ & - & - & - & $\begin{array}{l}98.9 \text { (Total } \\
\text { petroleum } \\
\text { hydrocarbon) }\end{array}$ & [29] \\
\hline 8 & - & $\begin{array}{l}\text { Dismulgan } \\
\text { V3377 }\end{array}$ & 7.0 & $9000-144000$ & $1-5$ & - & >99 (Oil removal) & [12] \\
\hline 9 & $\begin{array}{l}\text { Ferric chloride } \\
\left(\mathrm{FeCl}_{3}\right)\end{array}$ & $\mathrm{PACl}$ & 7.48 & - & 1 & - & 95 (COD and oil) & [71] \\
\hline 10 & $\begin{array}{l}\text { Polyaluminum } \\
\text { chloride (PACl) }\end{array}$ & $\begin{array}{l}\text { Cationic } \\
\text { polyacrylamide } \\
\text { (C-PAM) }\end{array}$ & 6.9 & $20-80$ & $2-20$ & 15 & $\begin{array}{l}98.1 \text { (TSS, } \\
\text { wastepaper) }\end{array}$ & [64] \\
\hline 11 & - & Polyacrylamide & 4.5 & 120 & $1-3$ & 5 & $\begin{array}{l}80-82 \text { (Sulfate- } \\
\text { sodium salts) }\end{array}$ & [73] \\
\hline 12 & $\mathrm{FeCl}_{3}$ and $\mathrm{PACl}$ & - & $7 / 6$ & - & 0.25 & 20 & $\begin{array}{l}\text { 96.38/95.38 (E. } \\
\text { coli) }\end{array}$ & {$[82]$} \\
\hline
\end{tabular}

In particular, ferric chloride $\left(\mathrm{FeCl}_{3}\right)$ and polyaluminum chlorides (PAC) are coagulants of inorganic character used very frequently in the treatment of water with high color and low turbidity [104], [106]. A study evaluated their efficiency in the waters of the Palacé River in the city of Popayán. It concluded that the use of $\mathrm{FeCl}_{3}$ as primary coagulant and PAC as coagulation coadjuvant generates flocs with higher sedimentation rates that facilitate turbidity removal and the optimization of sedimentation [106]. In another study, which investigated five aluminum coagulants to treat wastewater from a paper mill, DAF showed efficiencies between $85 \%$ and $90 \%$ in the removal of suspended solids, COD, and silica [107]. 
Currently, the study of coagulants, flocculants, and other substances of organic-type chemical action is an area of interest to researchers since these compounds tend to be environmentally friendly and could replace conventional chemicals [62], [63], [69]. In one study [71], more than $90 \%$ of $\mathrm{Cu}, \mathrm{As}$, and $\mathrm{Pb}$ were removed by magnetic biochar adsorption, recovering $90 \%$ of the biochar after the process. Oil removal studies with DAF have reported significant changes in the $\mathrm{pH}$, salinity, and temperature of oily waters using chemical reagents [108]. In addition [69], DAF has also been shown to be effective, with or without the use of biosurfactants, in treating oily waters.

DAF design parameters vary according to the hydrodynamics of the flotation tank, i.e., its geometry [48], [109], baffle angle (see Figure 2) [110], flotation kinetics [50], water inflow rate [111], the characteristics of the MB generating device [95], [101], surface tension, wastewater density, number of MBs, and MB rise velocity [28].

Another design parameter of DAF is the air-to-solid ratio (A/S), which is directly related to the required removal efficiency and indicates the mass of air required in the pressurization mechanism per unit mass of particles [46], [83]. This parameter, in turn, is associated with $\% \mathrm{R}$ and the amount of dissolved oxygen or air injected [22]. The equation for a system with only pressurized recycle is (1).

$$
\frac{A}{S}=\frac{1.3 C_{S}(f P-1) R}{X_{f} Q}
$$

where $C_{S}$ is the theoretical solubility of air $(\mathrm{mg} / \mathrm{L}) ; \mathrm{P}$, the absolute saturation pressure (atm); $\mathrm{f}$, the fraction of air dissolved at pressure $\mathrm{P}$, usually $0.5 ; \mathrm{R}$, the recirculation rate; $X_{f}$, the concentration of solids to be removed; and $\mathrm{Q}$, the flow that enters the flotation cell (L/s).

In DAF design, the required amount of air is determined by the concentration and size of the suspended particles [50]. The concentration of particles carried by the bubbles depends on their size, while the loading capacity is controlled by the availability of the total surface area [39], [45], [110].

Other parameters are also involved, such as Hydraulic Loading Capacity (HLC) (5-15 m/h in conventional DAF) [43], temperature, gas holdup [112], Recirculation Rate (\% R), air pressure, Surface Loading Rate (SLR) (15-30 m/h in high performance DAF equipment) [88], and Hydraulic Retention Time (HRT) [46], [58], [101]. However, six main design parameters are used in conventional DAF systems (see Table 7).

Salinity is another important parameter that could influence different aspects of DAF, such as air dissolution, bubble characteristics, and system hydrodynamics [67]. High air dissolution is critical in saline water DAF systems as it provides more opportunities for collision with suspended particles; moreover, about $50 \%$ of the operating costs are associated with air saturators [50].

An important tool to design DAF systems is Computational Fluid Dynamics (CFD). In numerical simulations of DAF using CFD, the flow regime is an essential parameter for flotation tank design, analysis, and control because it helps to improve the performance by directing heat and mass transfer [112]. The factors affecting the flow regime include the geometrical variables of the flotation tank (diameter, length, baffle angle, bubbler pore diameter, and cross-sectional area), particle size, dynamic variables (such as fluid flow velocity), and the physical properties of the wastewater [49]. 
Table 7. Main DAF design parameters. Source: Created by the authors

\begin{tabular}{|c|c|c|c|c|c|c|c|c|}
\hline No. & Ref. & $\begin{array}{l}\text { Inlet flow } \\
\text { rate }\left(\mathrm{m}^{3} / \mathrm{h}\right)\end{array}$ & $\begin{array}{l}\text { HRT } \\
(\min )\end{array}$ & $\begin{array}{l}\text { HLC } \\
(\mathrm{m} / \mathrm{h})\end{array}$ & $\begin{array}{l}\text { Air pressure } \\
\text { (psi) }\end{array}$ & $\begin{array}{c}\mathrm{A} / \mathrm{S} \\
(\mathrm{ml} / \mathrm{m}) \\
\end{array}$ & $\% \mathrm{R}$ & Removal efficiency (\%) \\
\hline 1 & {$[112]$} & 0.5 & - & - & $43.51-72.52$ & - & 10 & _- \\
\hline 2 & {$[22]$} & - & 120 & - & $14.50-75.52$ & - & - & $99\left(\mathrm{NH}_{4}{ }^{+}-\mathrm{N}\right)$ \\
\hline 3 & {$[45]$} & $1.8-2.4$ & $11-14$ & $11.4-15$ & 87.02 & & $20-25$ & $95\left(\mathrm{~Pb}^{2+}\right.$ and $\left.\mathrm{Cu}^{2+}\right)$ \\
\hline 4 & [58] & - & 4320 & - & 72.52 & - & 20 & $\begin{array}{l}\text { 89.4-90.95 (Total } \\
\text { phosphorus) } \\
\text { 90.2-92.6 (Total Kjeldahl } \\
\text { nitrogen TKN) }\end{array}$ \\
\hline 5 & [83] & 1.6-4 & $25-60$ & $10-22$ & 43.51-87.02 & 0.5 & $12-40$ & 94-96 (TSS) \\
\hline 6 & [103] & - & - & $11.8-23.4$ & - & 0.01 & - & - \\
\hline 7 & [61] & - & 1440 & - & $29.00-58.02$ & 0.026 & 30 & $\begin{array}{l}91.1 \pm 5.2(\text { Oil and grease }) \\
98.6 \pm 1.0(\mathrm{DBO})\end{array}$ \\
\hline 8 & {$[46]$} & - & $10-20$ & - & 89.92 & 0.35 & 40 & $\begin{array}{l}99(\mathrm{Ni}, \mathrm{Cu}, \mathrm{Cr}, \mathrm{Pb} \text { liquid } \\
\text { radioactive waste) }\end{array}$ \\
\hline
\end{tabular}

*\% R: Recirculation rate

Based on this literature review, Table 8 details the most relevant design and operating parameters in the three main DAF processes (i.e., chemical pretreatment, bubble generation, and flotation). The pretreatment of the wastewater at the coagulation-flocculation stage facilitates bubble-particle interaction and floc formation. The size of the bubbles generated is highly influential during the flotation process. Therefore, it should be set rigorously according to the characteristics of the generation device. Finally, the flotation process is directly determined by tank hydrodynamics, which influences the effectiveness of the operation.

Table 8. DAF's operating and design parameters classified by process. Source: Created by the authors.

\begin{tabular}{cccc}
\hline No. & Chemical pretreatment & Bubble generation & Flotation process \\
\hline 1 & $\mathrm{pH}$ & Temperature & SLR \\
2 & Coagulation-flocculation & $\% \mathrm{R} / \mathrm{S}$ & $\% \mathrm{R}$ \\
3 & Zeta potential & $\mathrm{A} / \mathrm{S}$ & MB size \\
4 & & Injected air flow & MB rise velocity \\
5 & Air pressure & Number of MBs \\
6 & Salinity & HRT \\
7 & Flow regime & HLC \\
8 & generator device characteristics & Air pressure \\
9 & pH & Flotation tank hydrodynamics \\
10 & Gas holdup & Particle size and concentration \\
11 & Zeta potential & \\
12 & Wastewater density
\end{tabular}

\section{DISCUSSION AND FUTURE SCOPE}

The literature has demonstrated the ability of DAF to remove high OM loads, particularly in the separation of oil and grease and FOG emulsions [12], [20], [68], [69] and fine suspended 
particles. In general, DAF has potential in the treatment of wastewater from agricultural, industrial, and domestic and municipal sectors. The recovery of raw material such as oils, nutrients, and minerals [108] and the generation of sludge from the flotation process could be sources of raw material for products such as biodiesel [47] and biogas [20], which, in turn, would help to alleviate waste discharge.

The number of publications between 2015 and 2021 (see Figure 4-a) examining the use of DAF for wastewater suggests that its application is less frequent in the agricultural sector, which represents $24 \%$ of the total documents. This could be because agricultural types of waste do not represent a complex problem in water treatment since they can become organic sources of coagulation, being an alternative to conventional metallic coagulants [63].

In contrast, the industrial sector was the most representative, with $44 \%$ of all the publications. This is likely due to the high amounts of oil and grease and microparticles in industrial wastewater, whose removal is facilitated by MBs due to the hydrophobicity of the medium and the density difference between the waste fluid (oil and grease in other chemical substances) and water [12], [15], [67], [68]. The application of DAF in municipal and domestic wastewater is relatively rare because it demands strict pretreatment with coagulants or flocculants due to the physicochemical and microbiological composition of this wastewater [22], [84]. However, this sector still accounted for $32 \%$ of the publications in the 2015-2021 period reviewed here (see Figure 4-b).

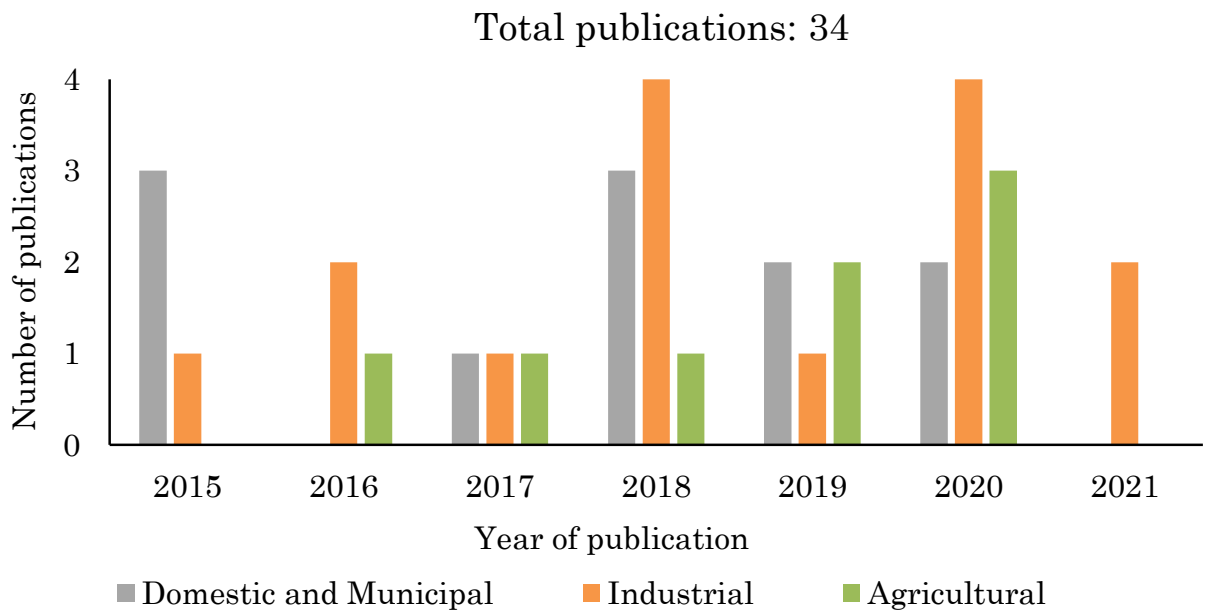

(a)

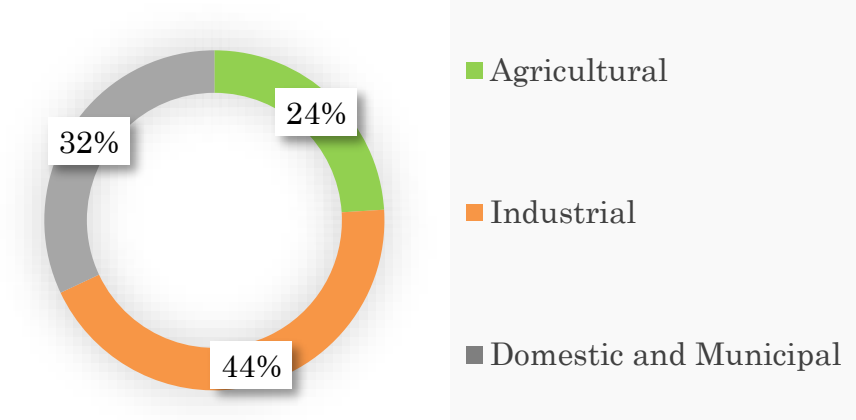

(b)

Figure 4. (a) Number of documents about the application of the DAF technique in the treatment of wastewater from the agricultural, industrial, and domestic and municipal sectors. (b) Proportions of the sectors in percentages. Source: Created by the authors. 
DAF has been in continuous development in recent years and has shown to be highly efficient in combination with other cleaning techniques [27], [30]. It is a key technique factored into future projects for improving the effectiveness of wastewater and drinking water treatment. Table 9 highlights its advantages [34], [45], [88], [102], [113] and disadvantages [71], [95], [75] in comparison with other wastewater treatment technologies.

Table 9. Advantages and disadvantages of DAF. Source: Created by the authors.

\begin{tabular}{|c|c|c|}
\hline No. & Advantages & Disadvantages \\
\hline 1 & $\begin{array}{l}\text { Efficient removal of OM, algae, oil and grease, FOG, } \\
\text { microparticles, and microorganisms from wastewater. }\end{array}$ & $\begin{array}{l}\text { The flotation tank must be protected from } \\
\text { low and high temperatures. }\end{array}$ \\
\hline 2 & $\begin{array}{l}\text { Fast system start-up, high separation efficiency, and } \\
\text { operational versatility. }\end{array}$ & $\begin{array}{l}\text { High energy consumption and increased } \\
\text { operating costs. }\end{array}$ \\
\hline 3 & Generation of thicker sludge. & DAF foam generation. \\
\hline 4 & $\begin{array}{l}\text { Compact system, low HRT, lower construction costs, low } \\
\text { operation cost, and high loading rates. }\end{array}$ & Use of coagulants and flocculants. \\
\hline
\end{tabular}

One particularity of DAF is that, in very cold climates, the system must be protected from low temperatures to avoid freezing the float and causing sedimentation of solids that have already been driven to the surface by the effect of the bubbles. This is because rising or falling temperatures in the flotation tank can affect gas retention and MB stability. In the case of a temperature increase, larger MBs break into smaller bubbles and the viscosity of the liquid is reduced, resulting in decreased stability due to oxygen reduction [16], [101].

Technological advances in DAF systems have stimulated new research into ways to optimize control, automation, operating times, system size, and energy costs, thus improving the efficiency of the overall process [48], [50]. For example, [32] analyzed the control and automation of a DAF pilot plant, where a SCADA was developed using OPC and Ethernet communication to monitor saturation pressure, liquid levels, and turbidity controls. The experiment achieved energy savings and improved performance in terms of the operation and operability of the plant. In a further study [114], turbidity control in DAF was studied using fuzzy logic, which led to improved control of this parameter and avoided excessive use of clean water in the recycling stream.

In addition, CFD allows researchers to examine various aspects of the flotation process by increasing the removal efficiency and decreasing investment and operating costs [28].

These mathematical models provide accurate information to design systems using optimal operating parameters. The results of CFD simulation can provide more practical information about the design and establish appropriate operating conditions [103], [109], [110]. In general, these studies tend to focus on analyzing fluid dynamics to explore the air/water flow and air distribution in the DAF tank [97], [99], [111].

Mathematical models and flow simulation of MBs using CFD have reduced the limitations of DAF systems and enabled advances in their operation and design to make them more efficient. For this reason, modern DAF system designs tend to be faster, more compact, and less expensive in operation [29], [83] compared to coagulation-sedimentation-filtration plants [45], [64], [110]. They also represent a considerable reduction in flocculation times and increased hydraulic loads [43], [88].

Studying the hydrodynamic characteristics of the flotation system is fundamental in the design, control, analysis, optimization, operation, and modeling of DAF equipment because these factors significantly affect the efficiency of the process [49], [50], [99]. Consequently, CFD allows researchers to predict the design and construction of DAF systems and identify 
the parameters needed to establish the optimal conditions for wastewater cleaning processes [102], [110].

The utilization of DAF sludge is an interesting avenue for future research as it can boost sustainable development and cleaner energy. A study [47] demonstrated the feasibility of using DAF sludge obtained from a meat processing plant as feedstock for biodiesel. Another one [20] evaluated the potential of DAF waste from food processing and poultry manure to optimize biogas production. Its results represent an opportunity to improve the economics of anaerobic digester systems based on organic farm waste used as feedstock that can also be recycled as fertilizer after digestion.

Finally, another interesting application of DAF is microalgae harvesting [105], [115], which is considered a cost-effective method for biofuel production [58], [116] that improves effluent quality. The effectiveness of DAF in the recovery of lipids from microalgae has been studied [108], and the results have shown high lipid recovery. DAF sludge utilization is an innovative research topic that can boost sustainable development with clean energy [108].

Wastewater treatment systems are increasingly facing new restrictions on emissions as well as tighter regulations on energy efficiency and resource recycling due to growing environmental pollution. An adequate configuration of the main design and operating parameters in DAF systems and their optimization at start-up can overcome many of these difficulties.

In general, the trend in DAF has been oriented towards improving removal efficiency and optimizing plant operating and energy costs. In this regard, flotation hydrodynamics is fundamental for the design, control, analysis, optimization, operation, and modeling of DAF [49], [50], [99], [114]. The latter involves flotation tank geometry and characteristic parameters of MBs [50].

The effects of DAF's operating and design parameters on the characteristics of the bubbles are remarkable, as they ensure the efficiency of bubble-particle floc formation and flocculation of the bubbles in the waste removal stage. In this respect, the parameters of both the tank hydrodynamics and the bubble-generating device must be considered in the design of DAF systems.

In order to establish optimal DAF operating parameters, it is essential to understand MB flow and interaction with surrounding particles [102], [110]. More studies should be conducted to optimize DAF processes in terms of reducing energy consumption. In addition, DAF could be optimized for locations with environmental conditions such as high or very low temperatures, so that they do not affect the performance of the water cleaning process. These improvements could make DAF a promising next-generation technology suitable for complex wastewater treatment processes.

DAF has proven its high performance in hybrid technologies, particularly in combination with biological methods, that meet the standards required by environmental legislation. DAF's effectiveness in reducing removal parameters (particularly turbidity, COD, BOD, TSS, and oil and grease, among other pollution indicators) makes it a recommendable technique for the recovery of water resources and the reduction of environmental toxicological risks.

\section{CONCLUSIONS}

This paper presented a systematic review of literature about the DAF method for wastewater treatment. This method has proven to be effective in treating wastewater of different characteristics generated by activities in the agricultural, industrial, and domestic and municipal sectors. Its MB-based technology has enabled the elimination of difficult-to- 
remove pollutants such as oil and grease, FOG, OM, and fine particles that are a problem in water reclamation processes. Over the past decade, significant progress has been made to increase the effectiveness of cleaning processes in DAF systems.

The selection of a set of design and operating parameters for DAF is directly related to wastewater characteristics. MB size, saturation pressure, dissolved oxygen concentration, recycle flow rate, and coagulation or flocculation are considered the main parameters in DAF due to their strong influence on system start-up. Currently, the most frequently used coagulants or flocculants in wastewater treatment are ferrous sulfate $\left(\mathrm{FeSO}_{4}\right)$ and polyacrylamide (PAM); however, natural alternatives such as ripe okra and passion fruit seed have shown promising results as replacements for artificial coagulants.

The advantages and disadvantages of DAF in wastewater treatment were also identified here to encourage new DAF studies in different areas of agribusiness, industry, and wastewater treatment, from the cleaning of facilities and equipment used in production processes to the treatment of drinking water. For instance, the generation of large amounts of DAF sludge can fill a gap in clean energy production since this waste can be used for biogas production and alleviate the waste discharge. Future research could enable the use of DAF sludge in other high-value activities. Finally, future work should focus on developing DAF technologies that use renewable energy, examine ways to reduce the energy consumption of elements (such as pressure pumps, motors, air compressors, and mechanical systems), and continue searching for natural coagulants and flocculants.

\section{ACKNOWLEDGMENTS}

The authors would like to thank the Universidad del Cauca for supporting this study.

\section{CONFLICTS OF INTEREST}

All the authors declare that they have no conflicts of interest.

\section{AUTHOR CONTRIBUTIONS}

Jeimmy Adriana Muñoz-Alegria: Conceptualization, methodology, data curation, and writing/original draft preparation.

Elena Muñoz España: Data visualization, research, supervision, writing, revising, and editing.

Juan Fernando Flórez-Marulanda: Data visualization, research, supervision, writing, revising, and editing.

\section{REFERENCES}

[1] UNESCO, The United Nations World Water Development Report 2019. Leaving no one behind. UNESCO. Digital Library. 2019. URL

[2] Agua.org.mx, Agua en el planeta. Fondo Para La Comunicación y La Educación Ambiental, A.C. 2017. URL

[3] H. Ritchie; M. Roser, Water Use and Stress. Our World in Data. 2017. URL

[4] SWAGL. Water in Agriculture: Towards Sustainable Agriculture. Washington, D.C. : World Bank Group. 2021. URL 
[5] A. Aziz; F. Basheer; A. Sengar; Irfanullah, S. U. Khan; I. H. Farooqi, "Biological wastewater treatment (anaerobic-aerobic) technologies for safe discharge of treated slaughterhouse and meat processing wastewater," Sci. Total Environ., vol. 686, pp. 681-708, Oct. 2019. https://doi.org/10.1016/j.scitotenv.2019.05.295

[6] A. Mirshafiee; A. Rezaee; R. S. Mamoory, "A clean production process for edible oil removal from wastewater using an electroflotation with horizontal arrangement of mesh electrodes," J. Clean. Prod., vol. 198, pp. 71-79, Oct. 2018. https://doi.org/10.1016/j.jclepro.2018.06.201

[7] C. J. Nawarkar; V. D. Salkar, "Solar powered Electrocoagulation system for municipal wastewater treatment," Fuel, vol. 237, pp. 222-226, Feb. 2019. https://doi.org/10.1016/j.fuel.2018.09.140

[8] H. Wu et al., "Comprehensive evaluation on a prospective precipitation-flotation process for metal-ions removal from wastewater simulants," J. Hazard. Mater., vol. 371, pp. 592-602, Jun. 2019. https://doi.org/10.1016/j.jhazmat.2019.03.048

[9] A. Azevedo; R. Etchepare; J. Rubio, "Raw water clarification by flotation with microbubbles and nanobubbles generated with a multiphase pump," Water Sci. Technol., vol. 75, no. 10, pp. 2342-2349, May. 2017. https://doi.org/10.2166/wst.2017.113

[10] A. Azevedo; H. Oliveira; J. Rubio, "Bulk nanobubbles in the mineral and environmental areas: Updating research and applications," Adv. Colloid Interface Sci., vol. 271, p. 101992, Sep. 2019. https://doi.org/10.1016/j.cis.2019.101992

[11] R. Etchepare; A. Azevedo; S. Calgaroto; J. Rubio, "Removal of ferric hydroxide by flotation with micro and nanobubbles," Sep. Purif. Technol., vol. 184, pp. $347-353, \quad$ Aug. 2017. https://doi.org/10.1016/j.seppur.2017.05.014

[12] H. A. Oliveira; A. C. Azevedo; R. Etchepare; J. Rubio, "Separation of emulsified crude oil in saline water by flotation with micro- and nanobubbles generated by a multiphase pump," Water Sci. Technol., vol. 76, no. 10, pp. 2710-2718, Nov. 2017. https://doi.org/10.2166/wst.2017.441

[13] T. Temesgen; T. T. Bui; M. Han; T. Kim; H. Park, "Micro and nanobubble technologies as a new horizon for water-treatment techniques: A review," Adv. Colloid Interface Sci., vol. 246, pp. 40-51, Aug. 2017. https://doi.org/10.1016/j.cis.2017.06.011

[14] R. Etchepare; H. Oliveira; A. Azevedo; J. Rubio, "Separation of emulsified crude oil in saline water by dissolved air flotation with micro and nanobubbles," Sep. Purif. Technol., vol. 186, pp. 326-332, Oct. 2017. https://doi.org/10.1016/j.seppur.2017.06.007

[15] M. W. Lim; E. V. Lau; P. E. Poh, "Micro-macrobubbles interactions and its application in flotation technology for the recovery of high density oil from contaminated sands," J. Pet. Sci. Eng., vol. 161, pp. 2937, Feb. 2018. https://doi.org/10.1016/j.petrol.2017.11.064

[16] K. Ruby; S. K. Majumder, "Studies on stability and properties of micro and nano-particle-laden ionic microbubbles," Powder Technol., vol. 335, pp. 77-90, Jul. 2018. https://doi.org/10.1016/j.powtec.2018.04.069

[17] M. Zhang; P. Guiraud, "Surface-modified microbubbles (colloidal gas aphrons) for nanoparticle removal in a continuous bubble generation-flotation separation system," Water Res., vol. 126, pp. 399-410, Dec. 2017. https://doi.org/10.1016/j.watres.2017.09.051

[18] S. Calgaroto; A. Azevedo; J. Rubio, "Separation of amine-insoluble species by flotation with nano and microbubbles," Miner. Eng., vol. 89, pp. 24-29, Apr. 2016. https://doi.org/10.1016/j.mineng.2016.01.006

[19] L. Zhang, "Advanced treatment of oilfield wastewater by a combination of DAF, yeast bioreactor, UASB, and BAF processes," Sep. Sci. Technol., vol. 56, no. 4, pp. 779-788, Mar. 2021. https://doi.org/10.1080/01496395.2019.1711411

[20] G. H. Johannesson; A. Crolla; J. D. Lauzon; B. H. Gilroyed, "Estimation of biogas co-production potential from liquid dairy manure, dissolved air flotation waste (DAF) and dry poultry manure using biochemical methane potential (BMP) assay," Biocatal. Agric. Biotechnol., vol. 25, p. 101605, May. 2020. https://doi.org/10.1016/j.bcab.2020.101605

[21] T. Wallace; D. Gibbons; M. O’Dwyer; T. P. Curran, "International evolution of fat, oil and grease (FOG) waste management - A review," J. Environ. Manage., vol. 187, pp. 424-435, Feb. 2017. https://doi.org/10.1016/j.jenvman.2016.11.003

[22] Q. Zhang; S. Liu; C. Yang; F. Chen; S. Lu, "Bioreactor consisting of pressurized aeration and dissolved air flotation for domestic wastewater treatment," Sep. Purif. Technol., vol. 138, pp. 186-190, Dec. 2014. https://doi.org/10.1016/j.seppur.2014.10.024

[23] T. Azuma et al., "Removal of pharmaceuticals in water by introduction of ozonated microbubbles," Sep. Purif. Technol., vol. 212, pp. 483-489, Apr. 2019. https://doi.org/10.1016/j.seppur.2018.11.059

[24] Y. Sun; S. Wang; J. Niu, "Microbial community evolution of black and stinking rivers during in situ remediation through micro-nano bubble and submerged resin floating bed technology," Bioresour. Technol., vol. 258, pp. 187-194, Jun. 2018. https://doi.org/10.1016/j.biortech.2018.03.008

[25] H. Al-Zoubi; K. A. Ibrahim; K. A. Abu-Sbeih, "Removal of heavy metals from wastewater by economical polymeric collectors using dissolved air flotation process," J. Water Process Eng., vol. 8, pp. 19-27, Dec. 
2015. https://doi.org/10.1016/j.jwpe.2015.08.002

[26] Y. Wang et al., "Interactions between flocs and bubbles in the separation zone of dissolved air flotation system," Sci. Total Environ., vol. 761, p. 143222, Mar. 2021. https://doi.org/10.1016/j.scitotenv.2020.143222

[27] Y. Wang et al., "A study on the feasibility and mechanism of enhanced co-coagulation dissolved air flotation with chitosan-modified microbubbles," J. Water Process Eng., vol. 40, p. 101847, Apr. 2021. https://doi.org/10.1016/j.jwpe.2020.101847

[28] K. Satpathy; U. Rehman; B. Cools; L. Verdickt; G. Peleman; I. Nopens, "CFD-based process optimization of a dissolved air flotation system for drinking water production," Water Sci. Technol., vol. 81, no. 8, pp. 1668-1681, Apr. 2020. https://doi.org/10.2166/wst.2020.028

[29] M. M. Amin; M. M. Golbini Mofrad; H. Pourzamani; S. M. Sebaradar; K. Ebrahim, "Treatment of industrial wastewater contaminated with recalcitrant metal working fluids by the photo-Fenton process as posttreatment for DAF," J. Ind. Eng. Chem., vol. 45, pp. 412-420, Jan. 2017. https://doi.org/10.1016/j.jiec.2016.10.010

[30] C. Cagnetta et al., "High-rate activated sludge systems combined with dissolved air flotation enable effective organics removal and recovery," Bioresour. Technol., vol. 291, p. 121833, Nov. 2019. https://doi.org/10.1016/j.biortech.2019.121833

[31] E. Villar-Navarro; R. M. Baena-Nogueras; M. Paniw; J. A. Perales; P. A. Lara-Martín, "Removal of pharmaceuticals in urban wastewater: High rate algae pond (HRAP) based technologies as an alternative to activated sludge based processes," Water Res., vol. 139, pp. 19-29, Aug. 2018. https://doi.org/10.1016/j.watres.2018.03.072

[32] R. R. Fonseca; J. P. Thompson Jr.; I. C. Franco; F. V. da Silva, "Automation and Control of a Dissolved Air Flotation Pilot Plant," IFAC-PapersOnLine, vol. 50, no. 1, pp. 3911-3916, Jul. 2017.https://doi.org/10.1016/j.ifacol.2017.08.364

[33] Y. Matsui; K. Fukushi; N. Tambo, "Modeling, simulation and operational parameters of dissolved air flotation," J. Water Supply Res. Technol., vol. 47, no. 1, pp. 9-20, Feb. 1998. https://doi.org/10.2166/aqua.1998.0003

[34] Z. Tian; C. Wang; M. Ji, "Full-scale dissolved air flotation (DAF) equipment for emergency treatment of eutrophic water," Water Sci. Technol., vol. 77, no. 7, pp. 1802-1809, Apr. 2018. https://doi.org/10.2166/wst.2018.046

[35] J. P. Bogacki; P. Marcinowski; J. Naumczyk; P. Wiliński, "Cosmetic wastewater treatment using dissolved air flotation," Arch. Environ. Prot., vol. 43, no. 2, pp. 65-73, Jun. 2017.https://doi.org/10.1515/aep-2017$\underline{0018}$

[36] S. Ahmadi; F. Mostafapour, "Survey of Efficiency of Dissolved Air Flotation in Removal Penicillin G Potassium from Aqueous Solutions," Br. J. Pharm. Res., vol. 15, no. 3, pp. 1-11, Jan. 2017. https://doi.org/10.9734/BJPR/2017/31180

[37] J. E. Forero; J. Diaz; V. R. Blandón, "Diseño de un nuevo sistema de flotación para el tratamiento de aguas industriales". C.T.F Cienc. Tecnol. Futuro, vol. 1, no. 5, pp. 67-75, Dic. 1999. URL

[38] J. E. Forero; O. P. Ortiz; J. J. Duque, "Design and application of flotation systems for the treatment of reinjected water in a colombian petroleum field", C.T.F Cienc. Tecnol. Futuro, vol. 3, no. 3, pp. 147-158, Jan. 2007. URL

[39] M.-S. Maeng; H.-S. Kim; K.-S. Lee; S. Dockko, "Effect of DAF configuration on the removal of phosphorus and organic matter by a pilot plant treating combined sewer overflows," Int. Biodeterior. Biodegradation, vol. 124, pp. 17-25, Oct. 2017. https://doi.org/10.1016/j.ibiod.2017.07.017

[40] F. A. Soares et al., "Dissolved air flotation as potential new mechanism for intestinal parasite diagnosis in feces," Acta Trop., vol. 224, p. 106137, Dec. 2021. https://doi.org/10.1016/j.actatropica.2021.106137

[41] K. Petersen; S. Vakkalanka; L. Kuzniarz, "Guidelines for conducting systematic mapping studies in software engineering: An update," Inf. Softw. Technol., vol. 64, pp. 1-18, Aug. 2015. https://doi.org/10.1016/j.infsof.2015.03.007

[42] A. Rahman; R. Mahdavi-Hezaveh; L. Williams, "A systematic mapping study of infrastructure as code research," Inf. Softw. Technol., vol. 108, pp. 65-77, Apr. 2019. https://doi.org/10.1016/j.infsof.2018.12.004

[43] J. K. Edzwald, "Dissolved air flotation and me," Water Res., vol. 44, no. 7, pp. 2077-2106, Apr. 2010. https://doi.org/10.1016/j.watres.2009.12.040

[44] M. Ansari; H. H. Bokhari; D. E. Turney, "Energy efficiency and performance of bubble generating systems," Chem. Eng. Process. - Process Intensif., vol. 125, pp. 44-55, Mar. 2018. https://doi.org/10.1016/j.cep.2017.12.019

[45] A. Azevedo; H. A. Oliveira; J. Rubio, "Treatment and water reuse of lead-zinc sulphide ore mill wastewaters by high rate dissolved air flotation," Miner. Eng., vol. 127, pp. 114-121, Oct. 2018. https://doi.org/10.1016/j.mineng.2018.07.011

[46] H. B. Ortiz-Oliveros; R. M. Flores-Espinosa, "Design of a mobile dissolved air flotation system with high rate for the treatment of liquid radioactive waste," Process Saf. Environ. Prot., vol. 144, pp. 23-31, Dec. 
2020. https://doi.org/10.1016/j.psep.2020.07.016

[47] O. V. Okoro; Z. Sun; J. Birch, "Meat processing dissolved air flotation sludge as a potential biodiesel feedstock in New Zealand: A predictive analysis of the biodiesel product properties," J. Clean. Prod., vol. 168, pp. 1436-1447, Dec. 2017. https://doi.org/10.1016/j.jclepro.2017.09.128

[48] V. R. Fanaie; M. Khiadani; T. Ayres, "Effects of internal geometry on hydrodynamics of dissolved air flotation (DAF) tank: An experimental study using particle image velocimetry (PIV)," Colloids Surfaces A Physicochem. Eng. Asp., vol. 575, pp. 382-390, Aug. 2019. https://doi.org/10.1016/j.colsurfa.2019.05.027

[49] R. Prakash; S. K. Majumder; A. Singh, "Flotation technique: Its mechanisms and design parameters," Chem. Eng. Process. - Process Intensif., vol. 127, pp. 249-270, May 2018. https://doi.org/10.1016/j.cep.2018.03.029

[50] V. R. Fanaie; M. Khiadani, "Effect of salinity on air dissolution, size distribution of microbubbles, and hydrodynamics of a dissolved air flotation (DAF) system," Colloids Surfaces A Physicochem. Eng. Asp., vol. 591, p. 124547, Apr. 2020. https://doi.org/10.1016/j.colsurfa.2020.124547

[51] M. de Langlard; H. Al-Saddik; S. Charton; J. Debayle; F. Lamadie, "An efficiency improved recognition algorithm for highly overlapping ellipses: Application to dense bubbly flows," Pattern Recognit. Lett., vol. 101, pp. 88-95, Jan. 2018.https://doi.org/10.1016/j.patrec.2017.11.024

[52] A. Gordiychuk; M. Svanera, S. Benini; P. Poesio, "Size distribution and Sauter mean diameter of micro bubbles for a Venturi type bubble generator," Exp. Therm. Fluid Sci., vol. 70, pp. 51-60, Jan. 2016. https://doi.org/10.1016/j.expthermflusci.2015.08.014

[53] R. Prakash; S. Kumar Majumder; A. Singh, "Bubble size distribution and specific bubble interfacial area in two-phase microstructured dense bubbling bed,” Chem. Eng. Res. Des., vol. 156, pp. 108-130, Apr. 2020. https://doi.org/10.1016/j.cherd.2020.01.032

[54] S. J. Gulden; C. Riedele; S. Rollié; M.-H. Kopf; H. Nirschl, "Online bubble size analysis in micro flotation," Chem. Eng. Sci., vol. 185, pp. 168-181, Aug. 2018. https://doi.org/10.1016/j.ces.2018.04.009

[55] L. Vinnett; J. Sovechles; C. O. Gomez; K. E. Waters, "An image analysis approach to determine average bubble sizes using one-dimensional Fourier analysis," Miner. Eng., vol. 126, pp. 160-166, Sep. 2018. https://doi.org/10.1016/j.mineng.2018.06.030

[56] B. Swart et al., "In situ characterisation of size distribution and rise velocity of microbubbles by high-speed photography," Chem. Eng. Sci., vol. 225, p. 115836, Nov. 2020. https://doi.org/10.1016/j.ces.2020.115836

[57] M. dos S. Pereira; A. C. Borges; F. F. Heleno; L. F. A. Squillace; L. R. D. Faroni, "Treatment of synthetic milk industry wastewater using batch dissolved air flotation,” J. Clean. Prod., vol. 189, pp. 729-737, Jul. 2018. https://doi.org/10.1016/j.jclepro.2018.04.065

[58] L. de S. Leite; M. T. Hoffmann; L. A. Daniel, "Coagulation and dissolved air flotation as a harvesting method for microalgae cultivated in wastewater," J. Water Process Eng., vol. 32, p. 100947, Dec. 2019. https://doi.org/10.1016/j.jwpe.2019.100947

[59] A. Castillo; P. Vall; M. Garrido-Baserba; J. Comas; M. Poch, "Selection of industrial (food, drink and milk sector) wastewater treatment technologies: A multi-criteria assessment," J. Clean. Prod., vol. 143, pp. 180190, Feb. 2017.https://doi.org/10.1016/j.jclepro.2016.12.132

[60] B. R. Baker; R. Mohamed; A. Al-Gheethi; H. A. Aziz, "Advanced technologies for poultry slaughterhouse wastewater treatment: A systematic review," J. Dispers. Sci. Technol., vol. 42, no. 6, pp. 880-899, May. 2021. https://doi.org/10.1080/01932691.2020.1721007

[61] V. Del Nery; M. H. Z. Damianovic; R. B. Moura; E. Pozzi; E. C. Pires; E. Foresti, "Poultry slaughterhouse wastewater treatment plant for high quality effluent," Water Sci. Technol., vol. 73, no. 2, pp. 309-316, Jan. 2016. https://doi.org/10.2166/wst.2015.494

[62] M. do S. Pereira; A. C. Borges; G. L. Muniz; F. F. Heleno; L. R. D. Faroni, "Dissolved air flotation optimization for treatment of dairy effluents with organic coagulants," J. Water Process Eng., vol. 36, p. 101270, Aug. 2020. https://doi.org/10.1016/j.jwpe.2020.101270

[63] G. L. Muniz; A. C. Borges; T. C. F. da Silva, "Performance of natural coagulants obtained from agroindustrial wastes in dairy wastewater treatment using dissolved air flotation," J. Water Process Eng., vol. 37, p. 101453, Oct. 2020. https://doi.org/10.1016/j.jwpe.2020.101453

[64] S. Ansari; J. Alavi; Z. M. Yaseen, "Performance of full-scale coagulation-flocculation/DAF as a pretreatment technology for biodegradability enhancement of high strength wastepaper-recycling wastewater," Environ. Sci. Pollut. Res., vol. 25, no. 34, pp. 33978-33991, Dec. 2018. https://doi.org/10.1007/s11356-018-3340-0

[65] M. M. G. Mofrad; H. Pourzamani; M. M. Amin; I. Parseh; M. Alipour, "In situ treatment of metalworking wastewater by chemical addition-dissolved air flotation coupled with UV, H2O2 \&amp; ZnO," Heliyon, vol. 6, no. 1, p. e03091, Jan. 2020. https://doi.org/10.1016/j.heliyon.2019.e03091

[66] Y. Shutova; B. L. Karna, A. C. Hambly, B. Lau, R. K. Henderson; P. Le-Clech, "Enhancing organic matter removal in desalination pretreatment systems by application of dissolved air flotation," Desalination, vol. 383, pp. 12-21, Apr. 2016. https://doi.org/10.1016/j.desal.2015.12.018 
[67] M. R. Aliff Radzuan; M. A. Abia-Biteo Belope; R. B. Thorpe, "Removal of fine oil droplets from oil-in-water mixtures by dissolved air flotation," Chem. Eng. Res. Des., vol. 115, pp. 19-33, Nov. 2016. https://doi.org/10.1016/j.cherd.2016.09.013

[68] M. Karhu; T. Leiviskä; J. Tanskanen, "Enhanced DAF in breaking up oil-in-water emulsions," Sep. Purif. Technol., vol. 122, pp. 231-241, Feb. 2014.https://doi.org/10.1016/j.seppur.2013.11.007

[69] F. C. P. Rocha e Silva et al., "Oil removal efficiency forecast of a Dissolved Air Flotation (DAF) reduced scale prototype using the dimensionless number of Damköhler," J. Water Process Eng., vol. 23, pp. 45-49, Jun. 2018. https://doi.org/10.1016/j.jwpe.2018.01.019

[70] C. Rattanapan; A. Sawain; T. Suksaroj; C. Suksaroj, "Enhanced efficiency of dissolved air flotation for biodiesel wastewater treatment by acidification and coagulation processes," Desalination, vol. 280, no. 1-3, pp. 370-377, Oct. 2011. https://doi.org/10.1016/j.desal.2011.07.018

[71] J. Lee et al., "Refractory oil wastewater treatment by dissolved air flotation, electrochemical advanced oxidation process, and magnetic biochar integrated system,” J. Water Process Eng., vol. 36, p. 101358, Aug. 2020. https://doi.org/10.1016/j.jwpe.2020.101358

[72] R. T. Rodrigues; J. Rubio, "DAF-dissolved air flotation: Potential applications in the mining and mineral processing industry," Int. J. Miner. Process., vol. 82, no. 1, pp. 1-13, Feb. 2007. https://doi.org/10.1016/j.minpro.2006.07.019

[73] J. Amaral Filho; A. Azevedo; R. Etchepare; J. Rubio, "Removal of sulfate ions by dissolved air flotation (DAF) following precipitation and flocculation,” Int. J. Miner. Process., vol. 149, pp. 1-8, Apr. 2016. https://doi.org/10.1016/j.minpro.2016.01.012

[74] J. Xue; H. Zhong; S. Wang, "Removal of sodium oleate from synthetic manganese leaching solution by coagulation-dissolved air flotation," J. Environ. Manage., vol. 247, pp. 1-8, Oct. 2019.https://doi.org/10.1016/j.jenvman.2019.06.026

[75] X. Zhang; X. Zhang; Y. Liu; Q. Zhang; S. Yang; X. He, "Removal of viscous and clogging suspended solids in the wastewater from acrylonitrile-butadiene-styrene resin production by a new dissolved air release device," Process Saf. Environ. Prot., vol. 148, pp. 524-535, Apr. 2021. https://doi.org/10.1016/j.psep.2020.10.031

[76] H. A. Oliveira; A. Azevedo; J. Rubio, "Removal of flocculated TiO 2 nanoparticles by settling or dissolved air flotation," Environ. Technol., vol. 42, no. 7, pp. 1001-1012, Mar. 2021.https://doi.org/10.1080/09593330.2019.1650123

[77] H. B. Ortiz-Oliveros; R. M. Flores-Espinosa, "Simultaneous removal of oil, total Co and 60Co from radioactive liquid waste by dissolved air flotation," Int. J. Environ. Sci. Technol., vol. 16, no. 7, pp. 3679. 3686, Jul. 2019. https://doi.org/10.1007/s13762-018-1984-4

[78] S. Watanabe et al., "STRAD project for systematic treatments of radioactive liquid wastes generated in nuclear facilities," Prog. Nucl. Energy, vol. 117, p. 103090, Nov. 2019. https://doi.org/10.1016/j.pnucene.2019.103090

[79] N. R. Hanumanth Rao et al., "The role of algal organic matter in the separation of algae and cyanobacteria using the novel 'Posi' - Dissolved air flotation process," Water Res., vol. 130, pp. 20-30, Mar. 2018. https://doi.org/10.1016/j.watres.2017.11.049

[80] A. H. Alshahri; L. Fortunato; N. Zaouri; N. Ghaffour; T. Leiknes, "Role of dissolved air flotation (DAF) and liquid ferrate on mitigation of algal organic matter (AOM) during algal bloom events in RO desalination," Sep. Purif. Technol., vol. 256, p. 117795, Feb. 2021. https://doi.org/10.1016/j.seppur.2020.117795

[81] H.-B. Ding; M. Doyle; A. Erdogan; R. Wikramanayake; P. Gallagher, "Innovative use of dissolved air flotation with biosorption as primary treatment to approach energy neutrality in WWTPs," Water Pract. Technol., vol. 10, no. 1, pp. 133-142, Mar. 2015. https://doi.org/10.2166/wpt.2015.015

[82] G. L. de Oliveira; L. A. Daniel, "Removal of Giardia spp. cysts and Cryptosporididum spp. oocysts from anaerobic effluent by dissolved air flotation," Environ. Technol., vol. 42, no. 1, pp. 141-147, Jan. 2021. https://doi.org/10.1080/09593330.2019.1625447

[83] O. Sanchez et al., "Recovery of particulate matter from a high-rate moving bed biofilm reactor by high-rate dissolved air flotation," Water Qual. Res. J., vol. 53, no. 4, pp. 181-190, Nov. 2018 https://doi.org/10.2166/wqrj.2018.003

[84] S. Choi; J. Shin; K.-J. Chae; Y. M. Kim, "Mitigation via physiochemically enhanced primary treatment of antibiotic resistance genes in influent from a municipal wastewater treatment plant," Sep. Purif. Technol., vol. 247, p. 116946, Sep. 2020. https://doi.org/10.1016/j.seppur.2020.116946

[85] T. Zheng et al., "Separation of Pollutants from Oil-Containing Restaurant Wastewater by Novel Microbubble Air Flotation and Traditional Dissolved Air Flotation," Sep. Sci. Technol., p. 150707113117003, Jul. 2015. https://doi.org/10.1080/01496395.2015.1062396

[86] F. C. Andreoli; L. P. Sabogal-Paz, "Coagulation, flocculation, dissolved air flotation and filtration in the removal of Giardia spp. and Cryptosporidium spp. from water supply," Environ. Technol., vol. 40, no. 5, pp. 654-663, Feb. 2019. http://dx.doi.org/10.1080/09593330.2017.1400113 
[87] D. Kotoula et al., "Municipal wastewater treatment by combining in series microalgae Chlorella sorokiniana and macrophyte Lemna minor: Preliminary results,” J. Clean. Prod., vol. 271, p. 122704, Oct. 2020. https://doi.org/10.1016/j.jclepro.2020.122704

[88] I. A. Crossley; M. T. Valade, "A review of the technological developments of dissolved air flotation," J. Water Supply Res. Technol., vol. 55, no. 7-8, pp. 479-491, Nov. 2006. https://doi.org/10.2166/aqua.2006.057

[89] M. Lichti; H.-J. Bart, "Bubble size distributions with a shadowgraphic optical probe," Flow Meas. Instrum., vol. 60, pp. 164-170, Apr. 2018. https://doi.org/10.1016/j.flowmeasinst.2018.02.020

[90] W. E. Juwana; A. Widyatama; O. Dinaryanto; W. Budhijanto; Indarto, and Deendarlianto, "Hydrodynamic characteristics of the microbubble dissolution in liquid using orifice type microbubble generator," Chem. Eng. Res. Des., vol. 141, pp. 436-448, Jan. 2019. https://doi.org/10.1016/j.cherd.2018.11.017

[91] X. Wang et al., "Bubble breakup in a swirl-venturi microbubble generator," Chem. Eng. J., vol. 403, p. 126397, Jan. 2021.https://doi.org/10.1016/j.cej.2020.126397

[92] R. Mazahernasab; R. Ahmadi, "Determination of bubble size distribution in a laboratory mechanical flotation cell by a laser diffraction technique," Physicochem. Probl. Miner. Process, vol. 52, no. 2, pp. 690702, Jul. 2014. URL

[93] N. Suwartha; D. Syamzida; C. R. Priadi; S. S. Moersidik; F. Ali, "Effect of size variation on microbubble mass transfer coefficient in flotation and aeration processes," Heliyon, vol. 6, no. 4, p. e03748, Apr. 2020. https://doi.org/10.1016/j.heliyon.2020.e03748

[94] X. Tao; Y. Liu; H. Jiang; R. Chen, "Microbubble generation with shear flow on large-area membrane for fine particle flotation," Chem. Eng. Process. - Process Intensif., vol. 145, p. 107671, Nov. 2019. https://doi.org/10.1016/j.cep.2019.107671

[95] A. Kouhestani; A. Amani Tehrani; H. Parsaeian; M. H. Nikfa; A. Bazargan; H. Masoumi Isfahani, "Study of 3D-Printed Pressure Release Nozzle for Microbubble Formation in Full-Scale Dissolved Air Flotation (DAF)," Chem. Eng. Process. - Process Intensif., vol. 155, p. 108070, Sep. 2020. https://doi.org/10.1016/j.cep.2020.108070

[96] W. Chung; S. Young, "Evaluation of a chemical dissolved air flotation system for the treatment of restaurant dishwasher effluent," Can. J. Civ. Eng., vol. 40, no. 12, pp. 1164-1172, Dec. 2013. https://doi.org/10.1139/cjce-2012-0357

[97] A. Chen; Z. Wang; J. Yang, "Influence of bubble size on the fluid dynamic behavior of a DAF tank: A 3D numerical investigation," Colloids Surfaces A Physicochem. Eng. Asp., vol. 495, pp. 200-207, Apr. 2016. https://doi.org/10.1016/j.colsurfa.2015.10.039

[98] T. Kim; H. Park; M. Han, "Design parameter estimations for adjustable bubble size in bubble generating system," Water Sci. Technol., vol. 77, no. 1, pp. 1-6, Jan. 2018. https://doi.org/10.2166/wst.2017.470

[99] J. P. Rodrigues; R. Béttega, "Evaluation of multiphase CFD models for Dissolved Air Flotation (DAF) process," Colloids Surfaces A Physicochem. Eng. Asp., vol. 539, pp. 116-123, Feb. 2018. https://doi.org/10.1016/j.colsurfa.2017.12.015

[100] J. Huang et al., "An investigation on the performance of a micro-scale Venturi bubble generator," Chem. Eng. J., vol. 386, p. 120980, Apr. 2020. . https://doi.org/10.1016/j.cej.2019.02.068

[101] Z. Pourkarimi; B. Rezai; M. Noaparast, "Effective parameters on generation of nanobubbles by cavitation method for froth flotation applications," Physicochem. Probl. Miner. Process, vol. 53, no. 2, pp. $920-942$. Aug. 2016. URL

[102] Y. Rybachuk; A. Jodłowski, "Mathematical model of dissolved air flotation (DAF) based on impulse conservation law," SN Appl. Sci., vol. 1, no. 6, p. 541, Jun. 2019. https://doi.org/10.1007/s42452-019-0560y

[103] B. Lakghomi; Y. Lawryshyn; R. Hofmann, "A model of particle removal in a dissolved air flotation tank: Importance of stratified flow and bubble size," Water Res., vol. 68, pp. 262-272, Jan. 2015. https://doi.org/10.1016/j.watres.2014.09.053

[104] J. Yanza-López; R. Rivera-Hernández; L. Gómez-Torres; C. Zafra-Mejía, "Evaluación de FeCl3 y PAC para la potabilización de agua con alto contenido de color y baja turbiedad," TecnoLógicas, vol. 22, no. 45, pp. 921, May 2019. https://doi.org/10.22430/22565337.1085

[105] K. Xu; Y. Li; X. Zou; H. Wen; Z. Shen; X. Ren, "Investigating microalgae cell-microsphere interactions during microalgae harvesting by ballasted dissolved air flotation through XDLVO theory," Biochem. Eng. J., vol. 137, pp. 294-304, Sep. 2018. https://doi.org/10.1016/j.bej.2018.06.013

[106] J. Fernández; S. Montenegro; C. Ledezma; J. Yanza, "Sedimentabilidad de partículas floculentas en aguas con alto contenido de color y baja turbiedad, coaguladas con FeCl3 + PAC versus PAC," TecnoLógicas, vol. 24, no. 51, p. e1789, Feb. 2021. https://doi.org/10.22430/22565337.1789

[107] R. Miranda; I. Latour; A. Blanco, "Understanding the Efficiency of Aluminum Coagulants Used in Dissolved Air Flotation (DAF)," Front. Chem., vol. 8, Feb. 2020. https://doi.org/10.3389/fchem.2020.00027

[108] F. Ghasemi Naghdi; P. M. Schenk, "Dissolved air flotation and centrifugation as methods for oil recovery from ruptured microalgal cells," Bioresour. Technol., vol. 218, pp. 428-435, Oct. 2016. 
https://doi.org/10.1016/j.biortech.2016.06.093

[109] H. S. Oh, S. H. Kang, S. Nam, E.-J. Kim; T.-M. Hwang, "CFD modelling of cyclonic-DAF (dissolved air flotation) reactor for algae removal," Eng. Sci. Technol. an Int. J., vol. 22, no. 2, pp. 477-481, Apr. 2019. https://doi.org/10.1016/j.jestch.2018.12.003

[110] K. H. Lee; H. Kim, J. W. KuK, J. D. Chung, S. Park; E. E. Kwon, "Micro-bubble flow simulation of dissolved air flotation process for water treatment using computational fluid dynamics technique," Environ. Pollut., vol. 256, p. 112050, Jan. 2020. https://doi.org/10.1016/j.envpol.2019.01.011

[111] J. P. Rodrigues; J. N. M. Batista; R. Béttega, "Application of population balance equations and interaction models in CFD simulation of the bubble distribution in dissolved air flotation," Colloids Surfaces A Physicochem. Eng. Asp., vol. 577, pp. 723-732, Sep. 2019. https://doi.org/10.1016/j.colsurfa.2019.06.032

[112] Y. Wang; W. Liu; L. Tian; R. Jia; Z. Du; A. Zhou, "Research on the CFD numerical simulation and process optimization of countercurrent-cocurrent dissolved air flotation," J. Water Supply Res. Technol., vol. 68, no. 5, pp. 325-336, Aug. 2019. https://doi.org/10.2166/aqua.2019.147

[113] A. Atamaleki et al., "Effect of coagulation and sonication on the dissolved air flotation (DAF) process for thickening of biological sludge in wastewater treatment," Environ. Heal. Eng. Manag., vol. 7, no. 1, pp. 5965, Feb. 2020. https://doi.org/10.34172/EHEM.2020.08

[114] R. R. Fonseca; I. C. Franco, J. P. Thompson; F. V. da Silva, "Turbidity control on dissolved air flotation process using fuzzy logic," Water Sci. Technol., vol. 78, no. 12, pp. 2586-2596, Dec. 2018. https://doi.org/10.2166/wst.2019.015

[115] X. Zhang; L. Wang; M. Sommerfeld; Q. Hu, "Harvesting microalgal biomass using magnesium coagulationdissolved air flotation," Biomass and Bioenergy, vol. 93, pp. 43-49, Oct. 2016. https://doi.org/10.1016/j.biombioe.2016.06.024

[116] M. A. S. Alkarawi,G. S. Caldwell; J. G. M. Lee, "Continuous harvesting of microalgae biomass using foam flotation,” Algal Res., vol. 36, pp. 125-138, Dec. 2018. https://doi.org/10.1016/j.algal.2018.10.018 